\title{
Pengaruh Olah Tanah dan Jenis Pupuk Kandang Terhadap Pertumbuhan dan Hasil Cabe Rawit Varietas Bara (Capsicum frutescens, L)
}

\author{
Agustinus Ajak ${ }^{a}$ dan Roberto I. C. O. Taolin ${ }^{b}$ \\ ${ }^{a}$ Fakultas Pertanian, Universitas Timor, Kefamenanu, TTU - NTT, Indonesia. \\ ${ }^{b}$ Fakultas Pertanian, Universitas Timor, Kefamenanu, TTU - NTT, Indonesia.
}

\section{Article Info}

\section{Article history:}

Received 20 Februari 2016

Received in revised form 17 April 2016

Accepted 18 Mei 2016

\section{Keywords:}

Olah Tanah

Pupuk Kandang

Capsicum frutescens, L

\begin{abstract}
Abstrak
Penelitian ini bertujuan untuk mengetahui pengaruh olah lahan dan jenis pupuk kandang terhadap pertumbuhan dan hasil cabe rawit sert mendapatkan jenis olah tanah dan pupuk kandang yang tepat. Penelitian mengunakan rancangan petak terbagi pola faktorial. Faktor petak utama adalah olah tanah yang terdiri dari tiga aras yaitu olah lubang, olah jalur dan olah maksimum. Faktor anak petak adalah jenis pupuk kandang yang terdiri dari tiga aras yaitu pupuk kandang sapi, pupuk kandang ayam dan pupuk kandang babi. Hasil penelitian menunjukan pengaruh interaksi antara olah tanah dan jenis pupuk hanya terjadi pada parameter berat buah per petak panen pertama. Olah tanah hanya memberikan pengaruh nyata terhadap suhu tanah 21 HST dan 63 HST dan diameter buah sedangkan jenis pupuk memberikan pengaruh yang nyata terhadap suhu tanah 42 HST, jumlah buah per tanaman, berat buah per tanaman, serta berat buah per petak panen I, panen II dan panen III. Olah jalur memberikan produksi cabe rawit tertinggi yakni 4,22 t/ha sedangkan jenis pupuk yang memberikan produksi tertinggi yakni pupuk kandang sapi yakni 4,30 t/ha. @2016 dipublikasikan oleh Savana Cendana.
\end{abstract}

\section{Pendahuluan}

Cabai rawit adalah tumbuhan yang populer sebagai bumbu masakan di berbagai negara. Buahnya digunakan sebagai sayuran, bumbu masak, acar dan asinan. Di dalam buah cabe rawit, terkandung capsaicin, kapsantin, karotenoid, alkaloid asiri, resin, minyak atsiri, vitamin A, dan Vitamin C. Capsaisin memberikan rasa pedas, berkhasiat untuk melancarkan aliran darah serta pemati rasa kulit. Bijinya mengandung solanine, solamidine, solamargine, solasodine, solasomine, dan steroid saponin (kapsisidin). Kapsisidin berkhasiat sebagai antibiotik (Iptek, 2010)

Bertanam cabai rawit dapat memberikan nilai ekonomi yang cukup tinggi apabila diusahakan dengan secara serius. Rata-rata hasil cabe di Kabupaten Timor Tengah Utara (TTU) hanya mencapai 30 t/ha (BPS TTU, 2010). Hasil cabe yang paling banyak terdapat di Kecamatan Biboki Utara mencapai $12 \mathrm{t} / \mathrm{ha}$.

Menurut Setyadi (2000), sistem pengolahan tanah yang bervariasi dapa memberikan hasil cabe rawit yang tidak seragam pula. Selanjutnya menurut Albayudi (2005), pengolahan tanah diperlukan apabila kondisi kepadatan tanah, aerasi tanah, kekuatan resisten tanah dan dalamnya perakaran tanaman tidak mendukung penyediaan air dan perkembangan akar. Dari hasil-hasil penelitian terdahulu terlihat bahwa pengolahan tanah yang intensif selalu memberikan hasil yang lebih tinggi (Nino, 2005)

Menurut Utomo (2005), degradasi tanah yang terjadi saat ini salah satunya sebagai akibat dari sistem olah tanah intensif atau pengolahan tanah sempurna seperti yang dilakukan kebanyakan petani. Pengolahan intensif dengan mencangkul dan membajak sampai gembur dan bersih tidak hanya berakibat buruk terhadap peningkatan degradasi tanah tetapi juga memakan banyak tenaga dan biaya dalam proses persipan lahan tanam. Anonim (2000), menyatakan pengolahan tanah minimum adalah pengolahan tanah secara terbatas dalam satu jalur atau parit, atau lubang yang akan ditanam. Lebih lanjut dinyatakan bahwa dengan pengolahan tanah minimum dapat menghindari kerusakan struktur tanah yang berlebihan sehingga erosi dapat dikurangi, tenaga kerja lebih sedikit sehingga mengurangi biaya pengolahan tanah, waktu persiapan lahan singkat, memperlambat proses mineralisasi sehingga penggunaan unsur hara dalam bahan-bahan organik lebih berkelanjutan

Selain pengolahan tanah yang tepat, peningkatan produktivitas tanah dan tanaman dapat juga dilakukan dengan cara pemberian pupuk kandang yang banyak tersedia di lingkungan masyarakat. Pupuk organik dari kotoran ternak antara lain pupuk kandang sapi, pupuk kandang ayam dan pupuk kandang babi. Permasalahanya adalah belum diketahui tentang pengaruh olah lahan dan jenis pupuk kandang terhadap pertumbuhan dan hasil cabe rawit. Penelitian in bertujuan untuk mengetahui pengaruh olah lahan dan jenis pupuk kandang terhadap pertumbuhan dan hasil cabe rawit serta mendapatkan jenis olah tanah dan pupuk kandang yang tepat.

\section{Metode}

Penelitian dilaksanakan bulan Agustus sampai November 2015 di kebun percobaan Fakultas Pertanian, Universitas Timor Kelurahan Sasi, Kecamatan Kota Kefamenanu, Kabupaten TTU.

Rancangan yang digunakan dalam penelitian ini adalah Rancangan Petak Terbagi (Split Plot Design) pola faktorial $3 \times 3$ yang diulang sebanyak tiga kali. Faktor petak utama adalah olah tanah $(\mathrm{Q})$ yang terdiri dari tiga aras yaitu olah lubang $\left(\mathrm{q}_{1}\right)$, olah jalur $\left(\mathrm{q}_{2}\right)$ dan olah maksimum $\left(\mathrm{q}_{3}\right)$. Faktor anak petak adalah jenis pupuk kandang $(\mathrm{P})$ yang terdiri dari tiga aras yaitu pupuk kandang sapi $\left(\mathrm{p}_{1}\right)$, pupuk kandang ayam $\left(\mathrm{p}_{2}\right)$ dan pupuk kandang babi $\left(\mathrm{p}_{3}\right)$

Data hasil pengamatan kemudian dianalisis dengan menggunakan sidik ragam (Anova) Rancangan Petak Terbagi (Split Plot Design). Rata-rata perlakuan selanjutnya diuji lanjut dengan menggunakan Duncan Multiple Range Test (DMRT) dengan tingkat signifikasi 5\% sesuai petunjuk Gomez dan Gomez, (1995). Analisis data menggunakan program SAS 9.1.

\section{Hasil dan Pembahasan}

\subsection{Suhu Tanah}

Hasil sidik ragam (Anova) menunjukkan bahwa tidak terjadi interaksi antara olah tanah dan jenis pupuk kandang terhadap suhu tanah setiap waktu pengamatan.

Jenis pengolahan tanah memberikan pengaruh utama terhadap suhu tanah saat pengamatan pertama dan terakhir, dimana saat 21 HST suhu tanah pada petak dengan olah jalur paling tinggi dan berbeda nyata dengan suhu tanah pada petak dengan olah lubang maupun olah jalur. Saat 42 HST jenis pengolahan tanah memberikan pengaruh utama terhadap suhu tanah tetapi suhu tanah pada petak dengan olah jalur tetap cenderung lebih tinggi, sedangkan saat 63 HST suhu tanah pada petak dengan olah tanah maximum paling tinggi dan berbeda nyata dengan suhu tanah pada petak dengan olah lubang tetapi tidak nyata berbeda dengan suhu tanah pada petak dengan olah jalur.

Saat 21 HST dan 63 HST, jenis pupuk kandang tidak berpengaruh nyata terhadap suhu tanah tetapi data pada Tebel 1. menunjukkan bahwa suhu tanah pada petak yang diberikan pupuk kandang babi selalu lebih tinggi. Saat 42 HST jenis pupuk kandang memberikan pengaruh yang nyata terhadap suhu tanah dimana suhu tanah pada petak yang diberikan pupuk kandang ayam dan babi sama tinggi dan berbeda nyata dengan suhu tanah pada petak yang diberikan pupuk kandang sapi.

Tabel 1. Suhu Tanah $\left({ }^{\circ} \mathrm{C}\right)$

\begin{tabular}{cccccc}
\hline \multirow{2}{*}{$\begin{array}{c}\text { Waktu } \\
\text { Pengamatan }\end{array}$} & \multirow{2}{*}{ Olah Tanah } & \multicolumn{3}{c}{ Jenis Pupuk Kandang } & \multirow{2}{*}{ Rerata } \\
\cline { 2 - 5 } & & Sapi & Ayam & Babi & \\
\hline \multirow{3}{*}{21 HST } & Lubang & 28,7 & 30,1 & 29,5 & $29,4 \mathrm{~b}$ \\
& Jalur & 33,5 & 32,0 & 35,3 & $33,6 \mathrm{a}$ \\
& Maksimum & 29,8 & 28,4 & 31,4 & $29,9 \mathrm{~b}$ \\
\cline { 2 - 5 } & Rerata & $30,7 \mathrm{a}$ & $30,2 \mathrm{a}$ & $32,0 \mathrm{a}$ & $(-)$ \\
\hline \multirow{3}{*}{42 HST } & Lubang & 26,7 & 28,8 & 29,4 & $28,3 \mathrm{a}$ \\
& Jalur & 29,3 & 29,1 & 28,6 & $29,0 \mathrm{a}$ \\
& Maksimum & 27,6 & 29,3 & 29,3 & $28,8 \mathrm{a}$ \\
\cline { 2 - 5 } & Rerata & $27,9 \mathrm{~b}$ & $29,1 \mathrm{a}$ & $29,1 \mathrm{a}$ & $(-)$ \\
\hline \multirow{3}{*}{63 HST } & Lubang & 27,0 & 27,2 & 27,4 & $27,2 \mathrm{~b}$ \\
& Jalur & 27,8 & 28,5 & 28,1 & $28,1 \mathrm{a}$ \\
& Maksimum & 28,7 & 28,4 & 28,8 & $28,6 \mathrm{a}$ \\
\cline { 2 - 5 } & Rerata & $27,8 \mathrm{a}$ & $28,0 \mathrm{a}$ & $28,1 \mathrm{a}$ & $(-)$ \\
\hline
\end{tabular}

Keterangan: Angka pada baris dan kolom yang diikuti dengan huruf yang sama tidak berbeda nyata menurut uji DMRT $\alpha 5 \%$ $(-)$ : Tidak terjadi interaksi antar faktor

\subsection{Tinggi Tanaman}

Hasil sidik ragam (Anova) menunjukkan bahwa tidak terjadi interaksi antara olah tanah dan jenis pupuk kandang terhadap tinggi tanaman setiap waktu pengamatan.

Jenis pengolahan tanah maupun jenis pupuk kandang juga tidak memberikan pengaruh utama masing-masing terhadap tinggi tanaman, tetapi data pada Tabel 2. menunjukkan bahwa saat pengamatan 21 HST tanaman yang ditanam pada petak dengan olah tanah maximum paling tinggi sedangkan tanaman yang ditanam pada petak dengan olah jalur paling pendek sedangkan saat pengamtan 42 HST dan 63 HST tanaman yang ditanam pada petak dengan olah lubang paling tinggi sedangkan tanaman yang ditanam pada petak dengan olah jalur tetap paling pendek.

Saat 21 HST dan 42 HST tanaman yang diberikan pupuk kandang ayam paling tinggi sedangkan tanaman yang diberikan pupuk kandang sapi paling 
pendek, saat 63 HST tanaman yang diberikan pupuk kandang babi paling tinggi sedangkan tanaman yang diberikan pupuk kandang sapi tetap paling pendek.

Tabel 2. Tinggi Tanaman $(\mathrm{cm})$

\begin{tabular}{cccccc}
\hline \multirow{2}{*}{$\begin{array}{c}\text { Waktu } \\
\text { Pengamatan }\end{array}$} & \multirow{2}{*}{ Olah Tanah } & \multicolumn{3}{c}{ Jenis Pupuk Kandang } & \multirow{2}{*}{ Rerata } \\
\cline { 2 - 5 } & & Sapi & Ayam & Babi & \\
\hline \multirow{3}{*}{21 HST } & Lubang & 18,3 & 17,7 & 16,9 & $17,6 \mathrm{a}$ \\
& Jalur & 15,9 & 18,7 & 16,5 & $17,0 \mathrm{a}$ \\
& Maksimum & 15,7 & 21,3 & 18,2 & $18,4 \mathrm{a}$ \\
\cline { 2 - 5 } & Rerata & $16,6 \mathrm{a}$ & $19,2 \mathrm{a}$ & $17,2 \mathrm{a}$ & $(-)$ \\
\hline \multirow{3}{*}{42 HST } & Lubang & 23,1 & 24,1 & 26,5 & $24,5 \mathrm{a}$ \\
& Jalur & 20,6 & 23,9 & 21,2 & $21,9 \mathrm{a}$ \\
& Maksimum & 19,7 & 25,7 & 23,7 & $23,0 \mathrm{a}$ \\
\cline { 2 - 5 } & Rerata & $21,1 \mathrm{a}$ & $24,5 \mathrm{a}$ & $23,8 \mathrm{a}$ & $(-)$ \\
\hline \multirow{3}{*}{63 HST } & Lubang & 27,6 & 32,9 & 31,1 & $30,5 \mathrm{a}$ \\
& Jalur & 24,4 & 23,5 & 27,1 & $25,0 \mathrm{a}$ \\
& Maksimum & 22,3 & 26,3 & 29,1 & $25,9 \mathrm{a}$ \\
\cline { 2 - 5 } & Rerata & $24,8 \mathrm{a}$ & $27,6 \mathrm{a}$ & $29,1 \mathrm{a}$ & $(-)$ \\
\hline
\end{tabular}

Keterangan : $\quad$ Angka pada baris dan kolom yang diikuti dengan huruf yang sama tidak berbeda nyata menurut uji DMRT $\alpha 5 \%$

$(-)$ : Tidak terjadi interaksi antar faktor

\subsection{Diameter Batang}

Hasil sidik ragam (Anova) menunjukkan bahwa tidak terjadi interaksi antara olah tanah dan jenis pupuk kandang terhadap diameter batang setiap waktu pengamatan.

Jenis pengolahan tanah maupun jenis pupuk kandang juga tidak memberikan pengaruh utama masing-masing terhadap diameter batang, tetapi data pada Tabel 3. menunjukkan bahwa batang tanaman yang ditanam pada petak dengan olah lubang selalu paling besar setiap kali pengamatan. Demikian juga dengan tanaman yang diberikan pupuk kandang ayam selalu berbatang lebih besar setiap kali pengamatan.

$\underline{\text { Tabel 3. Diameter Batang (mm) }}$

\begin{tabular}{cccccc}
\hline \multirow{2}{*}{$\begin{array}{c}\text { Waktu } \\
\text { Pengamatan }\end{array}$} & \multirow{2}{*}{ Olah Tanah } & \multicolumn{3}{c}{ Jenis Pupuk Kandang } & \multirow{2}{*}{ Rerata } \\
\cline { 2 - 5 } & & Sapi & Ayam & Babi & \\
\hline \multirow{3}{*}{$21 \mathrm{HST}$} & Lubang & 5,9 & 4,1 & 5,2 & $5,0 \mathrm{a}$ \\
& Jalur & 3,5 & 5,1 & 3,2 & $3,9 \mathrm{a}$ \\
& Maksimum & 2,8 & 4,1 & 3,3 & $3,4 \mathrm{a}$ \\
\cline { 2 - 5 } & Rerata & $4,1 \mathrm{a}$ & $4,4 \mathrm{a}$ & $3,9 \mathrm{a}$ & $(-)$ \\
\hline \multirow{3}{*}{$42 \mathrm{HST}$} & Lubang & 7,8 & 12,4 & 7,7 & $9,3 \mathrm{a}$ \\
& Jalur & 6,7 & 7,1 & 7,7 & $7,2 \mathrm{a}$ \\
& Maksimum & 7,5 & 8,4 & 8,9 & $8,3 \mathrm{a}$ \\
\cline { 2 - 5 } & Rerata & $7,3 \mathrm{a}$ & $9,3 \mathrm{a}$ & $8,1 \mathrm{a}$ & $(-)$ \\
\hline \multirow{3}{*}{63 HST } & Lubang & 9,8 & 15,0 & 14,6 & $13,1 \mathrm{a}$ \\
& Jalur & 13,6 & 12,2 & 10,2 & $12,0 \mathrm{a}$ \\
& Maksimum & 10,1 & 11,1 & 11,1 & $10,8 \mathrm{a}$ \\
\cline { 2 - 5 } & Rerata & $11,2 \mathrm{a}$ & $12,8 \mathrm{a}$ & $12,0 \mathrm{a}$ & $(-)$ \\
\hline
\end{tabular}

Keterangan : Angka pada baris dan kolom yang diikuti dengan huruf yang sama tidak berbeda nyata menurut uji DMRT $\alpha 5 \%$

$(-)$ : Tidak terjadi interaksi antar faktor

\subsection{Luas Daun}

Hasil sidik ragam (Anova) menunjukkan bahwa tidak terjadi interaksi antara olah tanah dan jenis pupuk kandang terhadap luas daun. Jenis pengolahan tanah maupun jenis pupuk kandang juga tidak memberikan pengaruh utama masingmasing terhadap luas daun, tetapi data pada Tabel 4. menunjukkan bahwa permukaan daun dari tanaman yang ditanam pada petak dengan olah tanah maximum paling luas sedangkan permukaan daun dari tanaman yang ditanam pada petak dengan olah lubang paling sempit. Permukaan daun dari tanaman yang diberikan pupuk kandang ayam paling luas sedangkan permukaan daun dari tanaman yang diberikan pupuk kandang babi paling sempit.

$\underline{\text { Tabel 4. Luas Daun }\left(\mathrm{cm}^{2}\right)}$

\begin{tabular}{ccccc}
\hline \multirow{2}{*}{ Olah Tanah } & \multicolumn{3}{c}{ Jenis Pupuk Kandang } & \multirow{2}{*}{ Rerata } \\
\cline { 2 - 4 } & Sapi & Ayam & Babi & \\
\hline Lubang & 386 & 301 & 85 & $257 \mathrm{a}$ \\
Jalur & 355 & 368 & 242 & $322 \mathrm{a}$ \\
Maksimum & 192 & 640 & 540 & $457 \mathrm{a}$ \\
\hline Rerata & $311 \mathrm{a}$ & $436 \mathrm{a}$ & $289 \mathrm{a}$ & $(-)$ \\
\hline Keterangan : & Angka pada baris dan kolom yang diikuti dengan huruf yang sama tidak \\
& berbeda nyata menurut uji DMRT $\alpha$ 5\% & \\
& $(-)$ : Tidak terjadi interaksi antar faktor &
\end{tabular}

\subsection{Diameter Buah}

Hasil sidik ragam (Anova) menunjukkan bahwa tidak terjadi interaksi antara olah tanah dan jenis pupuk kandang terhadap diameter buah. Jenis pengolahan tanah memberikan pengaruh utama yang nyata terhadap diameter buah dimana diameter buah dari tanaman yang ditanam pada petak dengan olah lubang paling besar dan berbeda nyata dengan diameter buah dari tanaman yang ditanam pada petak dengan olah maksimum tetapi tidak berbeda nyata dengan diameter buah dari tanaman yang ditanam pada petak dengan olah jalur.

Jenis pupuk kandang tidak memberikan pengaruh utama terhadap diameter buah, tetapi data pada Tabel 5. menunjukkan bahwa diameter buat dari tanaman yang diberikan pupuk kandang sapi paling besar sedangkan diameter buah dari tanaman yang diberikan pupuk kandang babi paling kecil.

$\underline{\text { Tabel 5. Diameter Buah (mm) }}$

\begin{tabular}{ccccc}
\hline \multirow{2}{*}{ Olah Tanah } & \multicolumn{3}{c}{ Jenis Pupuk Kandang } & \multirow{2}{*}{ Rerata } \\
\cline { 2 - 4 } & Sapi & Ayam & Babi & \\
\hline Lubang & 3,45 & 3,00 & 3,10 & $3,18 \mathrm{a}$ \\
Jalur & 2,89 & 2,97 & 2,81 & $2,89 \mathrm{ab}$ \\
Maksimum & 2,78 & 2,59 & 2,41 & $2,59 \mathrm{~b}$ \\
\hline Rerata & $3,04 \mathrm{a}$ & $2,85 \mathrm{a}$ & $2,77 \mathrm{a}$ & $(-)$ \\
\hline Keterangan : & Angka pada baris dan kolom yang diikuti dengan huruf yang sama tidak \\
& \multicolumn{3}{l}{ berbeda nyata menurut uji DMRT $\alpha$ 5\% } & \\
& $(-)$ : Tidak terjadi interaksi antar faktor & &
\end{tabular}

\subsection{Jumlah Buah Per Tanaman}

Hasil sidik ragam (Anova) menunjukkan bahwa tidak terjadi interaksi antara olah tanah dan jenis pupuk kandang terhadap jumlah buah per tanaman. Jenis pengolahan tanah juga tidak memberikan pengaruh utama terhadap jumlah buah per tanaman, tetapi data pada Tabel 6. menunjukkan bahwa buah setiap tanaman yang ditanam pada petak dengan olah jalur paling banyak sedangkan buah setiap tanaman yang ditanam pada petak dengan olah lubang paling sedikit.

Jenis pupuk kandang memberikan pengaruh utama yang nyata terhadap jumlah buah per tanaman dimana buah setiap tanaman yang diberikan pupuk kandang ayam paling banyak dan berbeda nyata dengan jumlah buah setiap tanaman yang diberikan pupuk kandang sapi tetapi tidak berbeda nyata dengan jumlah buah setiap tanaman yang diberikan pupuk kandang babi.

\section{Tabel 6. Jumlah Buah Per Tanaman}

\begin{tabular}{ccccc}
\hline \multirow{2}{*}{ Olah Tanah } & \multicolumn{3}{c}{ Jenis Pupuk Kandang } & \multirow{2}{*}{ Rerata } \\
\cline { 2 - 4 } & Sapi & Ayam & Babi & \\
\hline Lubang & 59,4 & 69,8 & 58,2 & $62,5 \mathrm{a}$ \\
Jalur & 59,8 & 85,8 & 75,8 & $73,8 \mathrm{a}$ \\
Maksimum & 59,6 & 88,6 & 63,2 & $70,5 \mathrm{a}$ \\
\hline Rerata & $59,6 \mathrm{~b}$ & $81,4 \mathrm{a}$ & $65,7 \mathrm{ab}$ & $(-)$
\end{tabular}

Keterangan : Angka pada baris dan kolom yang diikuti dengan huruf yang sama tidak berbeda nyata menurut uji DMRT $\alpha 5 \%$ $(-)$ : Tidak terjadi interaksi antar faktor

\subsection{Berat Buah Per Tanaman}

Hasil sidik ragam (Anova) menunjukkan bahwa tidak terjadi interaksi antara olah tanah dan jenis pupuk kandang terhadap berat buah per tanaman. Jenis pengolahan tanah juga tidak memberikan pengaruh utama terhadap berat buah per tanaman, tetapi data pada Tabel 7. menunjukkan bahwa buah setiap tanaman yang ditanam pada petak dengan olah jalur paling berat sedangkan buah setiap tanaman yang ditanam pada petak dengan olah maksimum paling ringan.

Jenis pupuk kandang memberikan pengaruh utama yang nyata terhadap berat buah per tanaman dimana buah setiap tanaman yang diberikan pupuk kandang ayam paling berat dan berbeda nyata dengan berat buah setiap tanaman yang diberikan pupuk kandang sapi tetapi tidak berbeda nyata dengan berat buah setiap tanaman yang diberikan pupuk kandang babi.

Tabel 7. Berat Buah Per Tanaman (g)

\begin{tabular}{ccccc}
\hline \multirow{2}{*}{ Olah Tanah } & \multicolumn{3}{c}{ Jenis Pupuk Kandang } & \multirow{2}{*}{ Rerata } \\
\cline { 2 - 4 } & Sapi & Ayam & Babi & \\
\hline Lubang & 109,9 & 125,2 & 106,5 & $113,9 \mathrm{a}$ \\
Jalur & 102,3 & 127,1 & 117,7 & $115,7 \mathrm{a}$ \\
Maksimum & 91,7 & 128,6 & 95,9 & $105,4 \mathrm{a}$ \\
\hline Rerata & $101,3 \mathrm{~b}$ & $127,0 \mathrm{a}$ & $106,7 \mathrm{ab}$ & $(-)$ \\
\hline Keterangan : & Angka pada baris dan kolom yang diikuti dengan huruf & yang sama tidak \\
& berbeda nyata menurut uji DMRT $\alpha$ 5\% & \\
& $(-)$ : Tidak terjadi interaksi antar faktor & &
\end{tabular}

\subsection{Jumlah Buah Per Anak Petak}

Hasil sidik ragam (Anova) menunjukkan bahwa tidak terjadi interaksi antara olah tanah dan jenis pupuk kandang terhadap jumlah buah per anak petak. Jenis pengolahan tanah maupun jenis pupuk kandang juga tidak memberikan pengaruh utama masing-masing terhadap jumlah buah per petak, tetapi data pada Tabel 8 . menunjukkan bahwa buah per petak dari tanaman yang ditanam pada petak 
dengan olah jalur paling banyak sedangkan buah per petak dari tanaman yang ditanam pada petak dengan olah lubang paling sedikit. Buah per petak dari tanaman yang diberikan pupuk kandang ayam paling banyak sedangkan buah per petak dari tanaman yang diberikan pupuk kandang babi paling sedikit.

Tabel 8. Jumlah Buah Per Anak Petak (x 10000)

\begin{tabular}{ccccc}
\hline \multirow{2}{*}{ Olah Tanah } & \multicolumn{3}{c}{ Jenis Pupuk Kandang } & \multirow{2}{*}{ Rerata } \\
\cline { 2 - 4 } & Sapi & Ayam & Babi & \\
\hline Lubang & 1119 & 1281 & 1078 & $1159 \mathrm{a}$ \\
Jalur & 1107 & 1552 & 1404 & $1354 \mathrm{a}$ \\
Maksimum & 1359 & 1637 & 970 & $1322 \mathrm{a}$ \\
\hline Rerata & $1195 \mathrm{a}$ & $1490 \mathrm{a}$ & $1150 \mathrm{a}$ & $(-)$
\end{tabular}

Keterangan : Angka pada baris dan kolom yang diikuti dengan huruf yang sama tidak berbeda nyata menurut uji DMRT $\alpha 5 \%$ $(-)$ : Tidak terjadi interaksi antar factor

\subsection{Berat Buah Per Anak Petak}

Hasil sidik ragam (Anova) menunjukkan bahwa pengaruh interaksi antara olah tanah dan jenis pupuk kandang terjadi saat panen I dimana buah per petak dari tanaman yang ditanam pada petak dengan olah lubang kemudian diberikan pupuk kandang sapi paling berat dan berbeda nyata dengan berat buah per petak yang diberikan kombinasi perlakuan lainnya kecuali buah per petak dari tanaman yang ditanam pada petak dengan olah jalur kemudian diberikan pupuk kandang sapi. Pada panen selanjutnya hingga total panen tidak terjadi interaksi antara olah tanah dan jenis pupuk kandang.

Jenis pengolahan tanah tidak memberikan pengaruh utama terhadap berat buah per petak setiap kali panen, tetapi data pada Tabel 9. menunjukkan bahwa saat panen I buah per petak dari tanaman yang ditanam pada petak dengan olah lubang paling berat sedangkan buah per petak dari tanaman yang ditanam pada petak dengan olah maksimum paling ringan, sebaliknya saat panen II buah per petak dari tanaman yang ditanam pada petak dengan olah maksimum yang paling berat sedangkan buah per petak dari tanaman yang ditanam pada petak dengan olah lubang yang paling ringan. Saat panen terakhir buah per petak dari tanaman yang ditanam pada petak dengan olah jalur yang paling berat sedangkan buah per petak dari tanaman yang ditanam pada petak dengan olah lubang tetap paling ringan, sedangkan hasil perhitungan total panen menunjukkan bahwa buah per petak dari tanaman yang ditanam pada petak dengan olah jalur paling berat sedangkan buah per petak dari tanaman yang ditanam pada petak dengan olah maksimum paling ringan.

Tabel 2. Berat Buah Per Anak Petak (t/ha)

\begin{tabular}{|c|c|c|c|c|c|}
\hline \multirow{2}{*}{$\begin{array}{c}\text { Waktu } \\
\text { Pengamatan }\end{array}$} & \multirow{2}{*}{ Olah Tanah } & \multicolumn{3}{|c|}{ Jenis Pupuk Kandang } & \multirow{2}{*}{ Rerata } \\
\hline & & Sapi & Ayam & Babi & \\
\hline \multirow{4}{*}{ Panen I } & Lubang & $3,92 \mathrm{a}$ & $2,78 \mathrm{bc}$ & $2,90 \mathrm{bc}$ & $3,20 \mathrm{a}$ \\
\hline & Jalur & $3,66 \mathrm{a}$ & $2,55 \mathrm{c}$ & $3,01 \mathrm{bc}$ & $3,07 \mathrm{a}$ \\
\hline & Maksimum & $2,88 \mathrm{bc}$ & $3,10 \mathrm{~b}$ & $2,84 \mathrm{bc}$ & $2,94 \mathrm{a}$ \\
\hline & Rerata & $3,49 \mathrm{a}$ & $2,81 \mathrm{~b}$ & $2,92 \mathrm{~b}$ & $(+)$ \\
\hline \multirow{4}{*}{ Panen II } & Lubang & 0,45 & 0,61 & 0,57 & $0,54 \mathrm{a}$ \\
\hline & Jalur & 0,41 & 0,72 & 0,68 & $0,60 \mathrm{a}$ \\
\hline & Maksimum & 0,39 & 0,82 & 0,73 & $0,65 \mathrm{a}$ \\
\hline & Rerata & $0,42 \mathrm{~b}$ & $0,72 \mathrm{a}$ & $0,66 \mathrm{ab}$ & $(-)$ \\
\hline \multirow{4}{*}{ Panen III } & Lubang & 0,30 & 0,57 & 0,26 & $0,38 \mathrm{a}$ \\
\hline & Jalur & 0,46 & 0,68 & 0,49 & $0,54 \mathrm{a}$ \\
\hline & Maksimum & 0,42 & 0,66 & 0,48 & $0,52 \mathrm{a}$ \\
\hline & Rerata & $0,39 \mathrm{~b}$ & $0,63 \mathrm{a}$ & $0,41 \mathrm{~b}$ & $(-)$ \\
\hline \multirow{4}{*}{ Total Panen } & Lubang & 4,68 & 3,95 & 3,73 & $4,12 \mathrm{a}$ \\
\hline & Jalur & 4,53 & 3,95 & 4,17 & $4,22 \mathrm{a}$ \\
\hline & Maksimum & 3,69 & 4,57 & 4,05 & $4,10 \mathrm{a}$ \\
\hline & Rerata & $4,30 \mathrm{a}$ & $4,16 \mathrm{a}$ & $3,99 \mathrm{a}$ & $(-)$ \\
\hline Keterangan : & $\begin{array}{l}\text { Angka pada ba } \\
\text { berbeda nyata } 1 \\
(-) \text { : Tidak ter }\end{array}$ & $\begin{array}{l}\text { dan kolon } \\
\text { hurut uji D } \\
\text { i interaksi }\end{array}$ & $\begin{array}{l}\text { g diikuti } \\
\Gamma \propto 5 \% \\
\text { factor }\end{array}$ & in huruf & \\
\hline
\end{tabular}

Jenis pupuk kandang memberikan pengaruh utama terhadap berat buah per petak saat panen I, II dan III. Saat panen I buah per petak dari tanaman yang diberikan pupuk kandang sapi paling berat dan berbeda nyata dengan berat buah per petak dari tanaman yang diberikan pupuk kandang ayam maupun babi, saat panen II buah per petak dari tanaman yang diberikan pupuk kandang ayam paling berat dan berbeda nyata dengan berat buah per petak dari tanaman yang diberikan pupuk kandang sapi tetapi tidak berbeda nyata dengan berat buah per petak dari tanaman yang diberikan pupuk kandang babi. Saat panen III buah per petak dari tanaman yang diberikan pupuk kandang ayam tetap paling berat dan berbeda nyata dengan berat buah per petak dari tanaman yang diberikan pupuk kandang sapi maupun babi. Jenis pupuk kandang tidak memberikan pengaruh utama terhadap berat buah per petak saat perhitungan total panen tetapi buah per petak dari tanaman yang diberikan pupuk kandang sapi paling berat sedangkan buah per petak dari tanaman yang diberikan pupuk kandang babi paling ringan.

\subsection{Berat Segar Berangkasan}

Hasil sidik ragam (Anova) menunjukkan bahwa tidak terjadi interaksi antara olah tanah dan jenis pupuk kandang terhadap berat segar berangkasan. Jenis pengolahan tanah maupun jenis pupuk kandang juga tidak memberikan pengaruh utama masing-masing terhadap berat segar berangkasan, tetapi data pada Tabel 10. menunjukkan bahwa berangkasan segar dari tanaman yang ditanam pada petak dengan olah lubang paling berat sedangkan berangkasan segar dari tanaman yang ditanam pada petak dengan olah tanah maksimum paling ringan. Berangkasan segar dari tanaman yang diberikan pupuk kandang babi paling berat sedangkan berangkasan segar dari tanaman yang diberikan pupuk kandang sapi paling ringan.

Tabel 3. Berat Segar Berangkasan (t/ha)

\begin{tabular}{ccccc}
\hline \multirow{2}{*}{ Olah Tanah } & \multicolumn{3}{c}{ Jenis Pupuk Kandang } & \multirow{2}{*}{ Rerata } \\
\cline { 2 - 4 } & Sapi & Ayam & Babi & \\
\hline Lubang & 7,30 & 18,89 & 16,19 & $14,13 \mathrm{a}$ \\
Jalur & 7,94 & 5,56 & 10,48 & $7,99 \mathrm{a}$ \\
Maksimum & 4,13 & 8,25 & 10,00 & $7,46 \mathrm{a}$ \\
\hline Rerata & $6,46 \mathrm{a}$ & $10,90 \mathrm{a}$ & $12,22 \mathrm{a}$ & $(-)$ \\
\hline Keterangan : & Angka pada baris dan kolom yang diikuti dengan huruf & yang sama tidak \\
& berbeda nyata menurut uji DMRT $\alpha$ 5\% & \\
& $(-)$ : Tidak terjadi interaksi antar faktor & &
\end{tabular}

\subsection{Berat Kering Berangkasan}

Hasil sidik ragam (Anova) menunjukkan bahwa tidak terjadi interaksi antara olah tanah dan jenis pupuk kandang terhadap berat kering berangkasan.

$\underline{\text { Tabel 11. Berat Kering Berangkasan (t/ha) }}$

\begin{tabular}{ccccc}
\hline \multirow{2}{*}{ Olah Tanah } & \multicolumn{3}{c}{ Jenis Pupuk Kandang } & \multirow{2}{*}{ Rerata } \\
\cline { 2 - 4 } & Sapi & Ayam & Babi & \\
\hline Lubang & 2,38 & 10,63 & 4,92 & $5,98 \mathrm{a}$ \\
Jalur & 1,43 & 2,38 & 5,71 & $3,17 \mathrm{a}$ \\
Maksimum & 2,46 & 2,70 & 4,37 & $3,17 \mathrm{a}$ \\
\hline Rerata & $2,09 \mathrm{a}$ & $5,24 \mathrm{a}$ & $5,00 \mathrm{a}$ & $(-$ ) \\
\hline Keterangan : & Angka pada baris dan kolom yang diikuti dengan huruf & yang sama tidak \\
& berbeda nyata menurut uji DMRT $\alpha$ 5\% & \\
& $(-)$ : Tidak terjadi interaksi antar faktor &
\end{tabular}

Jenis pengolahan tanah maupun jenis pupuk kandang juga tidak memberikan pengaruh utama masing-masing terhadap berat kering berangkasan, tetapi data pada Tabel 11. menunjukkan bahwa berangkasan kering dari tanaman yang ditanam pada petak dengan olah lubang paling berat sedangkan berangkasan kering dari tanaman yang ditanam pada petak dengan olah tanah maksimum paling ringan. Berangkasan kering dari tanaman yang diberikan pupuk kandang babi paling berat sedangkan berangkasan kering dari tanaman yang diberikan pupuk kandang sapi paling ringan.

\subsection{Indeks Panen}

Hasil sidik ragam (Anova) menunjukkan bahwa tidak terjadi interaksi antara olah tanah dan jenis pupuk kandang terhadap indeks panen. Jenis pengolahan tanah maupun jenis pupuk kandang juga tidak memberikan pengaruh utama masing-masing terhadap indeks panen, tetapi data pada Tabel 12 menunjukkan bahwa indeks panen dari tanaman yang ditanam pada petak dengan olah tanah maksimum paling tinggi sedangkan indeks panen dari tanaman yang ditanam pada petak dengan olah lubang paling rendah. Indeks panen dari tanaman yang diberikan pupuk kandang sapi paling tinggi sedangkan indeks panen dari tanaman yang diberikan pupuk kandang babi paling rendah.

\begin{tabular}{ccccc}
\multicolumn{3}{l}{ Tabel 12. Indeks Panen $(\%)$} & \multirow{2}{*}{ Rerata } \\
\hline \multirow{2}{*}{ Olah Tanah } & \multicolumn{3}{c}{ Jenis Pupuk Kandang } \\
\cline { 2 - 4 } & Sapi & Ayam & Babi & \\
\hline Lubang & 45,8 & 36,0 & 32,1 & $38,0 \mathrm{a}$ \\
Jalur & 54,4 & 45,0 & 28,4 & $42,6 \mathrm{a}$ \\
Maksimum & 55,7 & 37,5 & 46,5 & $46,5 \mathrm{a}$ \\
\hline Rerata & $52,0 \mathrm{a}$ & $39,5 \mathrm{a}$ & $35,6 \mathrm{a}$ & $(-)$ \\
\hline Keterangan : & Angka pada baris dan kolom yang diikuti dengan huruf & yang sama tidak \\
& berbeda nyata menurut uji DMRT $\alpha$ 5\% & \\
& $(-)$ : Tidak terjadi interaksi antar faktor &
\end{tabular}

\subsection{Pembahasan}

Pengolahan tanah dengan sistim olah jalur memberikan produksi cabe rawit yang tertinggi yakni 4,22 t/ha jika dibandingkan dengan olah lubang maupun olah maksimum. Produksi tertinggi ini dicapai karena dengan olah jalur menghasilkan jumlah buah setiap tanaman yang paling banyak sehingga buah setiap tanaman juga lebih berat dan jumlah buah setiap petaknya juga lebih banyak walaupun ukuran diameter buah yang dihasilkan tidak terlalu besar.

Pemberian pupuk kandang sapi memberikan produksi cabe rawit yang tertinggi yakni 4,30 t/ha dibandingkan dengan pemberian pupuk kandang ayam maupun babi. Dengan pemberian pupuk kandang sapi memang menghasilkan 
jumlah buah per petak yang tidak terlalu banyak tetapi ukuran diameter buah yang dihasilkan paling besar. Indeks panen cabe rawit yang dihasilkan dengan pemberian pupuk kandang sapi juga paling tinggi.

\section{Simpulan}

Interaksi antara olah tanah dan jenis pupuk hanya terjadi pada parameter berat buah per petak panen pertama. Olah tanah hanya memberikan pengaruh nyata terhadap suhu tanah 21 HST dan 63 HST dan diameter buah sedangkan jenis pupuk memberikan pengaruh yang nyata terhadap suhu tanah 42 HST, jumlah buah per tanaman, berat buah per tanaman, serta berat buah per petak panen I, panen II dan panen III.

Olah jalur memberikan produksi cabe rawit tertinggi yakni 4,22 t/ha sedangkan jenis pupuk yang memberikan produksi tertinggi yakni pupuk kandang sapi yakni 4,30 t/ha.

\section{Pustaka}

Anonim.2000. Pengelolaan sumber daya lahan kering di indonesia. Kumpulan informasi. Studio Drya Media . Bogor

BPS TTU. 2010. Timor Tengah Utara Dalam Angka. BPS TTU. Kefamenanu.

Gomez, K A dan Gomez A A. 1995. Prosedur Statistik untuk Penelitian Pertanian. Edisi ke 2. Jakarta: UI Press.

Iptek. 2010. Cabai Rawit (Diakses 20-02-2015). Tersedia pada http:/ /pertnanianpurworejo.com//2015

Nino.Y. 2005. Pengaruh pengolahan tanah dan pembenaman jenis bahan organic terhadap pertumbuhan dan hasil cabe rawit local timor (unu lilis) skripsi. Faperta Unimor Kefamenanu.

Setyadi. 2000. Bertanam cabe. Penebar swadaya. Jakarta. Hal.15

Utomo M. 2005. Pengelolaan lahan kering berkelanjutan. Seinar Nasional IAAS Indonesia. Mataram, Juli 2005. 